\section{キチンとキトサン (Chitin and Chitosan)}

1. キチンとキトサン

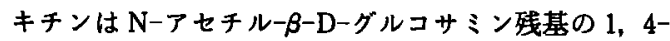
結合した化学構造の明確なホモ直銷多糖である゙1).この 多糖の研究歴史は古い. フランスの H. ブコノー （1811 年）がキノコの一成分に命名した "フォンジン" が,フランスの A. オジール (1823 年) により“キチン" と改名された. フランスのC.ルーゲ（1859年）はキチ ンの濃水酸化カリウム処理にてN-脱アセチル化誘導体 を調製した．この化合物にドイッの F。ホッペーザイラー (1894 年)が“キトサン”と命名した.なお，キトサンは キチンの N-脱アセチラーゼによる䣼素反応にても調製 できる(図参照).

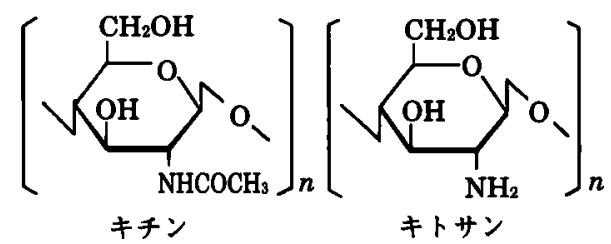

\section{2. キチンやキトサンを合む食品}

キチンはカニやエビなど甲殼類の殻, キノコなど菌類 の細胞壁などの構成成分で, 食品素材としてキノコ，パ ン酵母, エビ前餅，カ二珍味などは，世界各国にて古く より利用されている. キチンとキトサンは，日本，ロシ ヤ, 韓国, 台湾にて食品添加剤として承認されているが, キトサンはその他の国にて承認されていない.

\section{3. 血清コレステロール値の降下作用}

動物にて経口投与されたキトサンは酸性胃液に溶解し 小腸上部にてアルカリにて凝集し，腸壁から分泌される 胆汁酸と塩形成と共に食品中のコレステロールをミセル 中に取り込む．その結果，胆汁酸の肝㬴への偱環が阻害 され，血液中のコレステロールか胆汁酸の生成に使用さ れ，その值が低下する. キトサンは腸内細菌より分解利 用され，遊離胆汁酸が萁中へ排出される.

\section{DNA 合成とリソチーム活性の賦活}

動物の細胞培盖にてキチンやキトサンを培地に添加す ると細胞 DNA 合成が增し，細胞外リソチーム活性が賦 活する. キチンやキトサンの組織創傷部への添付や組織 内埋め込みにて組織リソチーム活性が上昇する.これら 醭素は病原菌の細胞壁を分解し，それらの感染を防いで いる.

\section{5. 鲜度保持剂}

野菜や果物の表面をキトサン処理すると $\mathrm{CO}_{2}$ とエチ レンの放出を抑制し，就成を遲らせ大腸菌など腐敗菌の 增殖を防き，野菜や果物の鮮度を保持する。

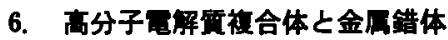

カチオンに荷電したキトサンは食品加工場からのアニ オン系廃液の浄化，また，工場廃液から有用タンパク質 や有用金属の回収に使用できる.

7. まとめ一生墛系の保全剂一

キチンとキトサンは食品, 莱品, 農荣, 肥料のいずれ であ無い. キチンやキトサンは植物にてフィトアレキシ ンやキチナーゼなど感染特異タンパク質の誘導, 動物に おける免度応答の増强, 抗腫湟活性など生物の外敵に対 する自己防御機能を細胞レベルにて向上する。また，土 境圈，水圈や動物消化器官における菌業を改善する. 地 球上にてキチンとキトサンは生合成と生分解が毎年絽り 返されている.この「地球上におけるキチンの自然循環」 が地球環境と生䔮系の保全に深く関与している゙2. キチ ンやキトサンは, 動物、微生物など全生物の生態系の病 気になるのを防ぐ保全㓮と結論できる.

\section{参考文献}

1） キチン・キトサン研究会 (編)：キチン・キトサ ンハンドブック，技報堂出版，1995.

2) HiRANo, S. : Some ecologically friendly applications of chitin and chitosan in biotechnology. In Industrial Biotechnological Polymers, eds. Gebelein, C.G. and CARRAher, E.C. Jr., (Technomic, Lancaster), 189 (1995).

(鳥取大学震学部 平野茂博) 